\title{
Growth of the Public Expenditures in India and its impact on the Deficits
}

\author{
Jasneet Kaur Wadhwa \\ (Department of Economics, SGTB Khalsa College, Delhi University, India)
}

\begin{abstract}
Before independence the British government in India was interested primarily in the civil administration and defence of the country. Therefore, a large part of the expenditures of the government was incurred on these services. Things have changed since independence. The Total Expenditures have increased rapidly because of increasing participation of the government in economic activities. The structure of the government Expenditures since the Eighties has been mainly influenced by a change in role of the government in the growth process, financing pattern of the deficits and the need for fiscal consolidation. Increasing expenditures of the government have led to an increase in the deficits of the government. Immediate response to economic crisis in 1991 was that of Expenditures compression because it was not easy to mobilize revenues. Fiscal consolidation was brought about by reducing the public expenditures and since then there has been a shift away from Plan Expenditures accompanied by a reduction in Development and Capital Expenditures.
\end{abstract}

Keywords - Deficits, Expenditure Reforms, India, Public Expenditures.

\section{INTRODUCTION}

Public Expenditures refer to government expenditures incurred by central, state and local governments of a country for the maintenance of the government, internal and external security and for the promotion of socio-economic welfare of the people. Governments all over the world assume certain responsibilities for the people of their country, the performance of which requires public expenditures. The government expenditures mainly consist of Expenditures on general, social and economic services.

\section{CLASSIFICATION OF PUBLIC EXPENDITURES}

Every year, the government prepares Estimates of Expenditures it is projecting to incur or has incurred in past and then puts it for a parliamentary approval (Article 112 - Indian Constitution) in the form of the budget document. This budget document classifies diverse expenses under various categories for better reporting, accounting and financial management purposes. The Central government had adopted a new classification of public Expenditures from the 1987-88 budget. Under this new classification all public expenditures are classified into:

- Plan Expenditures comprising of all the expenditures of the government which are included in the central plan. The expenditures related to new projects and programmes become Plan Expenditures during the period of a five year plan. Plan Expenditures are divided into Revenue and Capital Expenditures.

- Non-Plan Expenditures are committed expenditures on completed schemes of earlier plans and the interest on borrowings. Non-Plan Expenditures are further sub divided into Revenue Expenditures and Capital Expenditures. Revenue Expenditures relate to the day to day running expenses of the government and consists of interest payments, defence revenue expenditure, subsidies (food, fertilizers and export promotion and others), debt relief to farmers, postal deficit, police, pensions, other general services (organs of state, tax collection, external affairs, etc.). Capital Expenditures are those expenditures that lead to a creation of financial or physical assets or reduction in recurring financial liabilities. They include capital outlays and loans to states and union territories for financing plan projects, loans to foreign governments and loans to public enterprises.

There is another classification of government expenditures i.e., Development Expenditures and NonDevelopment Expenditures. Development Expenditures are broadly defined to include all items of expenditures that are designed directly to promote economic development and social welfare. It mainly includes spending on economic services (agriculture, industry, energy, communication, transport, science, technology and environment) and social services (education, health, employment, nutrition, housing and others). NonDevelopment Expenditures include expenditures pertaining to the general services rendered by the Government such as preservation of law and order, defence of the country and the maintenance of the general organs of the government. Expenditures by the government on social and economic services are a crucial necessity for 
fulfilling the basic needs of people in developing countries. However the share of the centre's expenditures on social services is low. Given the division of responsibilities between the Centre and the States in India, on an average about 85 percent of the spending in social services in India is undertaken by the state governments. It is the responsibility of the states, rather than the centre, to provide social services that matter more for human development. Further, states are responsible for most of the infrastructure facilities (except telecommunications, civil aviation, railways and major ports) and law and order.

\section{OBJECTIVES}

In this paper I will study the trends and structure of the expenditures of the Union Government of India since 1980s. I will then discuss the various fiscal reform measures undertaken during the period of study and their impact on the overall structure of the expenditures and deficits. It is also important to analyse and assess the usefulness of the expenditures reforms in reducing fiscal imbalance of the Central Government of India. The entire period of study, i.e. 1980-81 to 2011-12 will be divided in two parts i.e. pre reform and post reform period. Further, the paper will present the overall macroeconomic factors that have affected the expenditure decisions in the periods under study. Finally, an attempt is made to bring out a forward looking view on expenditure reforms that will be useful to plan a sustainable fiscal consolidation.

\section{DATA AND METHODOLOGY}

The study is based on secondary data collected from the various issues of the Reserve Bank of India Bulletin, Reports on Currency and Finance, Economic Survey and various reports of the Ministry of Finance, etc. While collecting the data on expenditures, I have primarily focused on the functional classification of the expenditures of the government. The functional classification is a detailed classification of the functions that the government aims to achieve through various kinds of outlays. The use of this classification permits a study of inter-temporal trends in government outlays on particular functions. The relevant statistical tools like averages and compound growth rates shall be used. Compound growth rates have been calculated by using the semi-log method i.e., $Y=a b^{n}$ where $Y$ is the revenue from the source, ' $n$ ' is the time period and ' $a$ ' is a constant. The growth rate is equal to $b-1$.

\section{TRENDS AND STRUCTURE OF THE UNION GOVERNMENT EXPENDITURES}

Table 2 shows that the total public expenditures have increased from Rs 231.94 billion in 1980-81 to Rs 13474.70 billion in 2011-12. The Total Expenditures grew at a very rapid pace in early eighties and after reaching a peak of 20.00 percent of the GDP (at current prices) in 1986-87 showed a sharp decline thereafter, falling to 14.54 percent in 1996-97 and moving up again to 16.87 percent in 2002-03. Post FRBMA it declined steadily to 13.90 percent in 2006-07 and climbed to 15.98 percent in 2008-09 due to the global financial crisis. The following year it went up further to 16.14 percent because of the expansionary fiscal policy adopted by the government plus the high expenditures on subsidies. Since then the economy has been on the path of recovery. Total Expenditures as a percentage of GDP has started showing a downward trend and in 2011-12 the ratio was 15.22 percent.

\section{DEVELOPMENT AND NON DEVELOPMENT EXPENDITURES}

Levels of Development Expenditures followed a trend similar to that of the total public expenditures. The share of Development Expenditures in the GDP rose after 1981-82 and reached its peak values in the mid 1980s. In the 1990s and 2000s, the share of Development Expenditures in GDP fell sharply. Thus, while there was a rise in the share of public expenditures and development expenditures in the GDP until the mid-eighties, the trend had reversed significantly in the nineties and continued in 2000s. An important factor that has been constraining the growth of Development Expenditures is the rising share of Non Development Expenditures. Non-Development Expenditures continues to be a large proportion of the Total Expenditures. Defense, debt services and administrative expenses are so large and so significant that they are responsible for keeping nonDevelopment Expenditures at a high level. The share of non-developmental expenditures in Total Expenditures of the Centre grew from 42.54 percent in 1980-81 to 45.70 percent in 1990-91 and 58.62 percent in 2000-01. Then in 2000s, post FRBMA the trend reversed and it fell to 47.21 percent in 2011-12 (Table 1).

\section{VI.I. Pre Reform Period}

During the eighties the main focus of the government was improvement in infrastructure therefore the expenditures on development activities like rural electrification, irrigation and flood control and rural upliftment was high. Table 1 reveals that the Development Expenditures as a percentage of Total Expenditures remained more than the Non Development Expenditures in eighties. Development Expenditures as a percent of total 
expenditures were 57.46 percent in $1980-81$, increased to 61.16 percent in 1985-86 then it reduced to 56.92 percent in 1989-90. As a percentage of GDP it increased from 8.91 percent in 1980-81 to 10.80 percent in 198990. During 1984-85 greater expenditures on social services were incurred and the expenditures on social services as a percent of GDP increased to 0.84 percent in 1984-85 from 0.67 percent in 1980-81. Crop insurance schemes, social security schemes and anti poverty programmes were launched in 1984-85. Many employment generation schemes and other rural development programmes were launched in 1987-88. Apart from these there was an increased expenditure on energy, transportation, railways, communication, health services and rural water supply, housing etc. The expenditures on economic services increased from 3.77 percent of GDP in 198081 to 5.10 percent in $1989-90$.

Table 1: Development and Non Development Expenditures of the Central Government

\begin{tabular}{|c|c|c|c|c|c|c|c|c|}
\hline \multirow{3}{*}{ Year } & \multicolumn{4}{|c|}{ (Rs billion) } & \multicolumn{4}{|c|}{ (as a percent of GDP) } \\
\hline & \multirow[b]{2}{*}{$\begin{array}{l}\text { Development } \\
\text { Expenditures }\end{array}$} & \multicolumn{2}{|c|}{ Of which } & \multirow{2}{*}{$\begin{array}{c}\text { Non- } \\
\text { Development } \\
\text { Expenditures }\end{array}$} & \multirow[b]{2}{*}{ DE } & \multicolumn{2}{|c|}{ Of which } & \multirow[b]{2}{*}{ NDE } \\
\hline & & $\begin{array}{l}\text { Economic } \\
\text { services }\end{array}$ & $\begin{array}{c}\text { Social } \\
\text { services }\end{array}$ & & & $\begin{array}{c}\text { Econ } \\
\text { omic } \\
\text { servic } \\
\text { es }\end{array}$ & $\begin{array}{c}\text { Social } \\
\text { service } \\
\text { s }\end{array}$ & \\
\hline 1980-81 & $133.27(57.46)$ & $56.44(24.33)$ & $10.08(4.35)$ & $98.67(42.54)$ & 8.91 & 3.77 & 0.67 & 6.59 \\
\hline 1981-82 & $137.91(52.17)$ & $67.37(25.49)$ & $12.44(4.71)$ & $126.44(47.83)$ & 7.84 & 3.83 & 0.71 & 7.19 \\
\hline $1982-83$ & $163.33(50.68)$ & $76.53(23.74)$ & $15.09(4.68)$ & $158.97(49.32)$ & 8.31 & 3.89 & 0.77 & 8.08 \\
\hline 1983-84 & $194.07(51.38)$ & $90.43(23.94)$ & $16.89(4.47)$ & $183.64(48.62)$ & 8.47 & 3.95 & 0.74 & 8.02 \\
\hline 1984-85 & $273.75(59.64)$ & $120.21(26.19)$ & $21.46(4.68)$ & $185.25(40.36)$ & 10.67 & 4.68 & 0.84 & 7.22 \\
\hline $1985-86$ & $329.09(61.16)$ & $140.14(26.04)$ & $14.96(2.78)$ & $208.99(38.84)$ & 11.37 & 4.84 & 0.52 & 7.22 \\
\hline 1986-87 & $354.98(54.80)$ & $162.75(25.12)$ & $21.61(3.34)$ & $260.60(40.23)$ & 10.96 & 5.02 & 0.67 & 8.04 \\
\hline 1987-88 & $365.73(51.91)$ & $157.22(22.31)$ & $23.69(3.36)$ & $302.61(42.95)$ & 9.93 & 4.27 & 0.64 & 8.22 \\
\hline 1988-89 & $415.36(50.95)$ & $180.22(22.11)$ & $27.69(3.40)$ & $355.19(43.97)$ & 9.51 & 4.13 & 0.63 & 8.13 \\
\hline 1989-90 & $542.04(56.92)$ & $256.02(26.89)$ & $30.61(3.21)$ & $410.20(43.08)$ & 10.80 & 5.10 & 0.61 & 8.17 \\
\hline $1990-91$ & $586.45(54.30)$ & $245.88(22.77)$ & $32.74(3.03)$ & $493.49(45.70)$ & 10.00 & 4.19 & 0.56 & 8.42 \\
\hline 1991-92 & $593.13(51.81)$ & $236.81(20.69)$ & $35.69(3.12)$ & $551.70(48.19)$ & 8.80 & 3.51 & 0.53 & 8.19 \\
\hline 1992-93 & $654.79(51.94)$ & $262.48(20.82)$ & $40.09(3.18)$ & $605.84(48.06)$ & 8.45 & 3.39 & 0.52 & 7.82 \\
\hline 1993-94 & $724.64(49.62)$ & 275.71(18.88) & $48.30(3.31)$ & $735.86(50.38)$ & 8.13 & 3.09 & 0.54 & 8.26 \\
\hline 1994-95 & $828.03(50.12)$ & $338.97(20.52)$ & $58.73(3.55)$ & $824.02(49.88)$ & 7.92 & 3.24 & 0.56 & 7.88 \\
\hline $1995-96$ & $844.27(46.12)$ & $350.29(19.14)$ & $76.55(4.18)$ & $986.32(53.88)$ & 6.88 & 2.86 & 0.62 & 8.04 \\
\hline 1996-97 & $941.97(45.63)$ & $372.53(18.05)$ & $96.72(4.69)$ & $1122.17(54.37)$ & 6.64 & 2.62 & 0.68 & 7.91 \\
\hline $1997-98$ & $1109.94(46.48)$ & $442.46(18.53)$ & $118.45(4.96)$ & $1278.20(53.52)$ & 7.06 & 2.81 & 0.75 & 8.13 \\
\hline 1998-99 & $1372.57(47.73)$ & $543.75(18.91)$ & $146.56(5.10)$ & $1502.98(52.27)$ & 7.61 & 3.02 & 0.81 & 8.33 \\
\hline 1999-00 & $1291.51(42.06)$ & $609.56(19.85)$ & $172.21(5.61)$ & $1779.28(57.94)$ & 6.42 & 3.03 & 0.86 & 8.84 \\
\hline 2000-01 & $1393.86(41.38)$ & $717.31(21.29)$ & $176.79(5.25)$ & $1974.70(58.62)$ & 6.43 & 3.31 & 0.82 & 9.11 \\
\hline 2001-02 & $1593.64(42.52)$ & $808.68(21.58)$ & $151.30(4.04)$ & $2154.56(57.48)$ & 6.79 & 3.44 & 0.64 & 9.17 \\
\hline 2002-03 & $1841.97(43.14)$ & $1038.20(24.32)$ & $220.07(5.15)$ & $2427.49(56.86)$ & 7.28 & 4.10 & 0.87 & 9.59 \\
\hline 2003-04 & $1954.28(44.54)$ & $1080.71(24.63)$ & $238.59(5.44)$ & $2432.98(55.46)$ & 6.89 & 3.81 & 0.84 & 8.57 \\
\hline 2004-05 & $2149.55(44.98)$ & $1150.30(24.07)$ & $299.06(6.26)$ & $2629.04(55.02)$ & 6.63 & 3.55 & 0.92 & 8.11 \\
\hline 2005-06 & $2290.60(44.07)$ & $1330.53(25.60)$ & $382.64(7.36)$ & $2906.77(55.93)$ & 6.20 & 3.60 & 1.04 & 7.87 \\
\hline 2006-07 & $2557.18(42.83)$ & $1427.72(23.92)$ & $437.62(7.33)$ & $3412.78(57.17)$ & 5.95 & 3.32 & 1.02 & 7.95 \\
\hline 2007-08 & $3256.70(44.83)$ & $1729.55(23.81)$ & $616.48(8.49)$ & $4007.28(55.17)$ & 6.53 & 3.47 & 1.24 & 8.04 \\
\hline 2008-09 & $4713.99(52.40)$ & $2732.22(30.37)$ & $897.97(9.98)$ & $4281.45(47.60)$ & 8.37 & 4.85 & 1.59 & 7.60 \\
\hline 2009-10 & $5282.42(50.68)$ & $3044.40(29.21)$ & $1026.28(9.85)$ & $5141.01(49.32)$ & 8.18 & 4.71 & 1.59 & 7.96 \\
\hline 2010-11 & $6660.69(54.71)$ & $4043.12(33.21)$ & $1249.90(10.27)$ & $5514.71(45.29)$ & 8.68 & 5.27 & 1.63 & 7.19 \\
\hline
\end{tabular}


Growth of the Public Expenditures in India and its impact on the Deficits

\begin{tabular}{|c|c|c|c|c|c|c|c|c|}
\hline 2011-12 & $7112.76(52.79)$ & $4504.12(33.43)$ & $1077.56(8.00)$ & $6361.94(47.21)$ & 8.03 & 5.09 & 1.22 & 7.18 \\
\hline
\end{tabular}

Non Development Expenditures increased during this period owing to increased interest rates and defence expenditures. As a percentage of GDP, Non Development Expenditures increased from 6.59 percent in 1980-81 to 8.17 percent in 1989-90. External debts were increasing and large portion of the borrowed funds was loaned to weaker sections of the society at subsidized rates. As a percentage of Total Expenditures the share of Non Development Expenditures remained almost stable. It was 42.54 percent in $1980-81$, dipped slightly in 1984-85 to 40.36 percent and rose back to 43.08 percent in 1989-90.

The average compound growth rate of Development Expenditures remained high at 15.06 percent during this period. The average compound growth rate of the Non Development Expenditures and Total Expenditures were around 15.31 percent and 15.17 percent during the same time period (Table 3).

\section{VI.II. Post Reform Period}

In the 1990s the Development Expenditures started declining. With the introduction of the reforms the composition of expenditures started changing towards Non Development Expenditures. Development Expenditures as a percentage of Total Expenditures in 1990-91 were 54.30 percent which came down to 42.06 percent in 1999-2000. On the other hand the share of Non Development Expenditures in Total Expenditures increased from 45.70 percent in 1990-91 to 57.94 percent in 1999-2000 (Table 1). As a percentage of GDP the rate of Development Expenditures came down from 10.00 percent in 1990-91 to 6.42 percent in 1999-2000. In 2000s, the Development Expenditures as a percentage of Total Expenditures started rising again. As a share of Total Expenditures, Development Expenditures have risen from 41.38 percent in 2000-01 to 52.79 percent in 2011-12. This was on account of slowdown of reforms since 1996-97, the drought of 2002-03 and the growth objectives of FRBMA. Development Expenditures as a percentage of GDP rose from 6.43 percent in 2000-01 to 7.28 percent in 2002-03. Then it started declining again and came down to 5.95 percent in 2006-07 and rose to 8.37 percent in 2008-09. On account of the increased Development Expenditures due to expansionary fiscal stance followed by the government post global financial and economic crisis in 2008-09, the Development Expenditures have remained in that range with 8.03 percent in 2011-12.The share of Non Development Expenditures during the nineties remained stable with a marginal increase from 8.42 percent in 1990-91 to 8.84 percent in 1999-2000. Non Development Expenditures as a percentage of GDP continued to fall throughout the next decade. It was 9.11 percent in 2000-01, came down to 7.60 percent in 2008-09 and has been recorded at 7.18 percent in 2011-12. As a percentage of Total Expenditures, Non Development Expenditures fell from 58.62 percent in 2000-01 to 47.21 percent in 2011-12 showing a reversal of the situation from 1990s.

The compound growth rate of Development Expenditures had declined to 8.21 percent in the nineties as compared to 15.66 percent in the eighties. Then it rose once again to 14.25 percent in 2000-10. On the other hand the compound growth rate of Non Development Expenditures had decreased from 15.31 percent in the eighties to 13.68 percent in the nineties. It continued to fall gradually keeping up with the earlier trend and was 10.04 percent in 2000s (Table 3).

The share of Social Services Expenditures by the Centre in the GDP which was rising in the early 1980s started falling thereafter till 1992-93 where it was 0.52 percent of GDP. The ratio rose again to 0.86 percent in 1999-2000, fell for some time and went back to 0.87 percent in 2002-03. This rising trend then continued for long and the ratio was recorded at 1.59 percent in 2008-09. As a share of the Total Expenditures, Social Services Expenditures show similar trends. The share of Social Services Expenditures in Total Expenditures rose significantly in the early 1980 s, then in $1985-86$ it fell down to 2.78 percent. The ratio remained stable till 1994-95, then it rose again in the latter half of nineties. In 2000-01 it was 5.25 percent, 2002-03 onwards the ratio has been consistently rising and was 10.27 percent in 2010-11. Economic services after having increased in the eighties, fell down gradually in the nineties, falling down to 2.62 percent in 199697. Thereafter the ratio hovered around 3-4 percent throughout the 2000s, increasing to 4.85 percent in 2008-09 and further going up to 5.27 percent in 2010-11. As a percentage of Total Expenditures the economic services have remained in the range of 23-25 percent throughout the period of study except a fall in the late nineties. In 2008-09 the ratio increased to 30.37 percent and has further gone up to 33.43 percent in 2011-12. Bharat Nirman, a time-bound plan for rural infrastructure by the Government of India in partnership with State Governments and Panchayati Raj Institutions, remained the cornerstone of the Government's policy in late 2000s. The eight flagship programmes of the Government continued to receive high priority and significant increase in allocations were made in Mid-day Meal Scheme, National Rural Employment, Rajiv Gandhi Drinking Water Mission, Total Sanitation Campaign, National Rural Health Mission, Integrated Child 
Development Programme, Sarva Siksha Abhiyan, Guarantee Scheme and Jawaharlal Nehru National Urban Renewal Mission.

Thus, we see that during the eighties the Development Expenditures as a percent of GDP have been more than Non Development Expenditures because of the development programmes launched by the government and increased expenditures on social services. Then in the nineties Non Development Expenditures as a percent of GDP have been more than Development Expenditures and have continued to increase with an exception in 2002-03. Post FRBMA, Non Development Expenditures as a percent of GDP have continued to fall. In 2008-09 the Development Expenditures as a percent of GDP increased and became more than Non Development Expenditures thus putting the economy on the path of recovery.

\section{Plan AND NON Plan EXPENDitures}

Table 2 shows that the Plan Expenditures share in the Total Expenditures declined in 1980s and through 1990s. It was 39.50 percent in 1980-81 and declined to 26.94 percent in 1989-90. It then started rising and peaked of 30.78 percent in 1993-94. Thereafter the trend reversed again and the Plan Expenditures in 200001was 25.39 percent of the Total Expenditures. Though the share of Plan Expenditures improved to 29.29 percent in 2007-08, it continued to be low in relation to the previous decades. Post the global financial crisis and the adoption of expansionary fiscal policy by the government to deal with the crisis, the ratio started rising again and went up to 32.35 percent. In the year 2011-12 the Plan Expenditures have increased to Rs 4266.04 billion from Rs 89.94 billion in 1980-81, showing an absolute increase of about 45 times. The Non-Plan Expenditures increased by about 65 times from 137.74 billion to Rs 8921.16 billion during the same period.

As a percentage of Total Expenditures the share of Non-Plan Expenditures increased from 60.50 percent in 1980-81 to 74.61 percent in 2000-01. It then remained stable for some time and came down to 68.86 percent in 2008-09, subsequently increasing to 70.39 percent in 2009-10 and was at 67.65 percent in 2011-12. Interest payments, defense expenditures, subsidies and general services, together form more than 90 percent of the Non plan Expenditures which are difficult to control with the ever-growing public debt and other liabilities.

\section{VII.I. Pre Reform Period}

The emphasis of economic policies in the eighties was on strengthening the productive potential of the economy on one hand and on expanding the programmes directly benefiting the weaker, poor and underprivileged sections of the society on the other. As a result, the Plan Expenditures as a percentage of GDP increased from 6.01 percent in 1980-81 to 7.10 percent in 1986-87. Non-Plan Expenditures also went up from 9.20 percent to 12.32 percent during the same period (Table 2) because of increased borrowings to meet the deficits (and thus over mounting interest payments) and increasing subsidies along with high defense expenditures. In second half of the 1980s, Long Term Fiscal Policy (LTFP) was announced for the first time where the need for moderation in the growth of Non-Plan Expenditures was emphasized. However, the NonPlan Expenditures remained high during this period. The main reasons for high growth in Non-Plan Expenditures during this period were draught faced by the major parts of the country during the years 1985-88 and implementations of $4^{\text {th }}$ pay commission recommendations. In the latter half of the eighties, the Plan Expenditures started to decline. As a percentage of GDP the Plan Expenditures reduced from 6.86 percent in 1985-86 to 5.48 percent in 1989-90.

The Non-Plan Expenditures were increasing at a greater pace as compared to Plan Expenditures and the compound rate of growth in the Non-Plan Expenditures was 16.85 percent during this decade as compared to the Plan Expenditures which grew at a compounded rate of 11.83 percent (Table 3).

\section{VII.II. Post Reform Period}

To achieve fiscal consolidation it was important to contain the Non-Plan Expenditures. For this effect the government decontrolled the phosphoric and potassium fertilizers in 1992 and also announced the increase in the petroleum product prices, thus reducing the petroleum subsidy. So the trend of the eighties reversed and Non Plan Expenditures started to show a declining trend. As a percentage of GDP the Non-Plan Expenditures which was 13.12 percent in 1990-91 reduced to 11.03 percent in 1999-2000. Another reason for a fall in NonPlan Expenditures during this period was reduction of posts at various levels of the government.

The falling trend of Non-Plan Expenditures continued during the nineties, except a setback of 1997-98, when there was a sharp escalation in its salary bill due to the implementation of the recommendations of the Fifth Central Pay Commission. As a result Non-Plan Expenditures as a percentage of GDP increased from 10.39 percent in 1996-97 to 11.00 percent and 11.78 percent in the next two years. The Plan Expenditures reduced from 4.84 percent in 1990-91 to 3.79 percent in 1999-2000.

In the beginning of the decade 2000-10, the Plan Expenditures increased on account of increased investments in different sectors. Non-Plan Expenditures rose because of the increase in food and fertilizers subsidies and relief measures taken to contain the effects of draught faced by the nation. 2003-04 onwards i.e. post FRBMA there 
was a moderation in growth of Non-Plan Expenditures and as a percentage of GDP it fell from 12.30 percent in 2003-04 to 10.18 percent in 2007-08. The reversal of the trend of fiscal consolidation was marked in 2008-09 and 2009-10 due to the expansionary fiscal stance undertaken during the global financial crisis. Plan Expenditures was at 4.89 percent of the GDP in 2008-09 and has remained about the same with 4.82 percent recorded in 2011-12. Non-Plan Expenditures as a percentage of GDP after going up to 10.81 percent and 11.17 percent in 2008-09 and 2009-10 declined to 10.07 percent in 2011-12 due to significant reform initiatives in expenditures. As a proportion of Total Expenditures the share of Plan Expenditure decreased from 26.94 percent in 1990-91 to 25.39 percent in 2000-01. However, it increased to 31.66 percent in 2010-11. Non plan expenditure on the other hand increased from 73.06 percent in 1990-91 to 74.61 percent in 2000-01 and thereafter decreased to 67.65 percent in 2010-11 confirming to the falling trend of Non Plan Expenditures measured against GDP.

Table 2: Plan and Non Plan Expenditures of the Central Government

\begin{tabular}{|c|c|c|c|c|c|}
\hline year & $\begin{array}{c}\text { Plan } \\
\text { Expenditures } \\
\text { (Rs. Billion) }\end{array}$ & $\begin{array}{c}\text { Non Plan } \\
\text { Expenditures } \\
\text { (Rs. Billion) }\end{array}$ & $\begin{array}{c}\text { Total } \\
\text { Expenditures } \\
\text { (Rs. Billion) }\end{array}$ & $\begin{array}{c}\text { PE } \\
\text { (as a percent of } \\
\text { GDP) }\end{array}$ & $\begin{array}{c}\text { NPE } \\
\text { (as a percent of } \\
\text { GDP) }\end{array}$ \\
\hline $1980-81$ & $89.94(39.50)$ & $137.74(60.50)$ & 227.68 & 6.01 & 9.20 \\
\hline 1985-86 & $198.54(37.70)$ & $328.12(62.30)$ & 526.66 & 6.86 & 11.33 \\
\hline $1986-87$ & $229.96(36.55)$ & $399.20(63.45)$ & 629.16 & 7.10 & 12.32 \\
\hline $1987-88$ & $242.09(35.47)$ & $440.52(64.53)$ & 682.61 & 6.57 & 11.96 \\
\hline $1988-89$ & $259.51(32.80)$ & $531.60(67.20)$ & 791.11 & 5.94 & 12.17 \\
\hline $1989-90$ & $275.20(29.62)$ & $653.88(70.38)$ & 929.08 & 5.48 & 13.03 \\
\hline 1990-91 & $283.65(26.94)$ & 769.33(73.06) & 1052.98 & 4.84 & 13.12 \\
\hline 1991-92 & $309.61(27.79)$ & $804.53(72.21)$ & 1114.14 & 4.59 & 11.94 \\
\hline $1992-93$ & $366.61(29.90)$ & $859.57(70.10)$ & 1226.18 & 4.73 & 11.10 \\
\hline 1993-94 & $436.62(30.78)$ & $981.91(69.22)$ & 1418.53 & 4.90 & 11.02 \\
\hline 1994-95 & $473.78(29.48)$ & $1133.61(70.52)$ & 1607.39 & 4.53 & 10.84 \\
\hline $1995-96$ & $463.74(26.01)$ & 1319.01(73.99) & 1782.75 & 3.78 & 10.75 \\
\hline $1996-97$ & $535.34(26.63)$ & $1474.73(73.37)$ & 2010.07 & 3.77 & 10.39 \\
\hline $1997-98$ & $590.77(25.46)$ & $1729.76(74.54)$ & 2320.53 & 3.76 & 11.00 \\
\hline 1998-99 & $668.18(23.92)$ & $2125.22(76.08)$ & 2793.40 & 3.71 & 11.78 \\
\hline 1999-00 & $761.82(25.56)$ & $2218.71(74.44)$ & 2980.53 & 3.79 & 11.03 \\
\hline 2000-01 & $826.69(25.39)$ & $2429.23(74.61)$ & 3255.92 & 3.81 & 11.20 \\
\hline 2001-02 & 1011.94(27.93) & 2611.16(72.07) & 3623.10 & 4.31 & 11.12 \\
\hline 2002-03 & $1114.70(26.97)$ & $3017.78(73.03)$ & 4132.48 & 4.40 & 11.92 \\
\hline 2003-04 & $1222.80(25.95)$ & $3489.23(74.05)$ & 4712.03 & 4.31 & 12.30 \\
\hline 2004-05 & $1322.92(26.55)$ & $3659.60(73.45)$ & 4982.52 & 4.08 & 11.29 \\
\hline 2005-06 & $1406.38(27.81)$ & $3651.00(72.12)$ & 5057.38 & 3.81 & 9.89 \\
\hline 2006-07 & 1698.60(29.12) & $4135.27(70.88)$ & 5833.87 & 3.96 & 9.63 \\
\hline 2007-08 & $2102.83(29.29)$ & $5075.89(70.71)$ & 7178.72 & 4.22 & 10.18 \\
\hline 2008-09 & $2752.35(31.14)$ & $6087.21(68.86)$ & 8839.56 & 4.89 & 10.81 \\
\hline 2009-10 & $3033.91(29.61)$ & $7210.96(70.39)$ & 10244.87 & 4.70 & 11.17 \\
\hline 2010-11 & $3790.39(31.66)$ & $8182.89(68.34)$ & 11973.28 & 4.94 & 10.66 \\
\hline 2011-12 & $4266.04(32.35)$ & $8921.16(67.65)$ & 13187.20 & 4.82 & 10.07 \\
\hline
\end{tabular}

*Figures for 2011-12 are revised estimates.

Figures in brackets are a percentage of total expenditures

Source: Government of India, ministry of finance, Indian public finance statistics, 2011-12

The over loading of Plan Expenditures is evident from the levels of compound growth of 13.88 percent in this decade as against 10.38 percent in the nineties. On the other hand the compound rate of growth of NonPlan Expenditures was 11.49 percent as against 11.17 percent in the nineties (Table 3). 
Table 3: Compound Rates of Growth of the Expenditures of the Central Government

\begin{tabular}{|l|l|l|l|l|}
\hline Decade & $\begin{array}{c}\text { Development } \\
\text { Expenditures }\end{array}$ & $\begin{array}{c}\text { Non Development } \\
\text { Expenditures }\end{array}$ & $\begin{array}{c}\text { Plan } \\
\text { Expenditures }\end{array}$ & $\begin{array}{c}\text { Non Plan } \\
\text { Expenditures }\end{array}$ \\
\hline $1980-1989$ & 15.06 & 15.31 & 11.83 & 16.85 \\
\hline $1990-1999$ & 8.21 & 13.68 & 10.38 & 11.17 \\
\hline $2000-2009$ & 10.04 & 13.88 & 11.49 \\
\hline
\end{tabular}

\section{REVENUE AND CAPITAL EXPENDITURES}

The first major trend in public expenditures which we observe in India is the growing Revenue Expenditures of the government from Rs. 144.10 billion in 1980-81 to Rs. 11619.40 billion in 2011-12 which is an 80 fold increase. Increased defence commitments, expansion of administration, the government's international commitments, increase in government's participation in nation building activities like education and public health, rise in prices, etc. are responsible for the increased Revenue Expenditures of the Central Government. Capital Expenditures during the same period increased about 20 times, from Rs. 83.58 billion in 1980-81 to Rs. 1567.80 billion in 2011-12 (Table 4).

Table 4: Revenue and Capital Expenditures of the Central Government

\begin{tabular}{|c|c|c|c|c|c|c|}
\hline \multirow[b]{2}{*}{ Year } & \multirow{2}{*}{$\begin{array}{c}\text { Revenue } \\
\text { Expenditures } \\
\text { (Rs. Billion) }\end{array}$} & \multirow{2}{*}{$\begin{array}{c}\text { Capital } \\
\text { Expenditures (Rs. } \\
\text { Billion) }\end{array}$} & \multirow{2}{*}{$\begin{array}{c}\text { Total } \\
\text { Expenditures } \\
\text { (Rs. Billion) }\end{array}$} & \multicolumn{3}{|c|}{ As a percent of GDP } \\
\hline & & & & $\begin{array}{c}\text { Revenue } \\
\text { Expenditures }\end{array}$ & $\begin{array}{c}\text { Capital } \\
\text { Expenditures }\end{array}$ & $\begin{array}{c}\text { Total } \\
\text { Expenditure } \\
\mathrm{s}\end{array}$ \\
\hline 1980-81 & $144.10(63.29)$ & $83.58(36.71)$ & 227.68 & 9.63 & 5.59 & 15.21 \\
\hline 1981-82 & $154.08(60.99)$ & $98.57(39.01)$ & 252.65 & 8.76 & 5.61 & 14.37 \\
\hline $1982-83$ & $187.42(60.87)$ & $120.49(39.13)$ & 307.91 & 9.53 & 6.13 & 15.66 \\
\hline 1983-84 & $222.51(62.62)$ & $132.83(37.38)$ & 355.34 & 9.72 & 5.80 & 15.52 \\
\hline 1984-85 & $276.91(63.46)$ & $159.41(36.54)$ & 436.32 & 10.79 & 6.21 & 17.00 \\
\hline 1985-86 & $339.24(64.41)$ & $187.42(35.59)$ & 526.66 & 11.72 & 6.47 & 18.19 \\
\hline 1986-87 & $408.60(64.94)$ & $220.56(35.06)$ & 629.16 & 12.61 & 6.81 & 19.42 \\
\hline 1987-88 & $461.74(67.64)$ & $220.87(32.36)$ & 682.61 & 12.54 & 6.00 & 18.54 \\
\hline 1988-89 & $541.06(68.39)$ & $250.05(31.61)$ & 791.11 & 12.38 & 5.72 & 18.11 \\
\hline 1989-90 & $642.10(69.11)$ & $286.98(30.89)$ & 929.08 & 12.79 & 5.72 & 18.51 \\
\hline 1990-91 & $735.16(69.82)$ & $317.82(30.18)$ & 1052.98 & 12.54 & 5.42 & 17.96 \\
\hline 1991-92 & $822.92(73.86)$ & $291.22(26.14)$ & 1114.14 & 12.21 & 4.32 & 16.53 \\
\hline $1992-93$ & $927.02(75.50)$ & $299.16(24.40)$ & 1226.18 & 11.97 & 3.86 & 15.83 \\
\hline 1993-94 & $1081.69(76.25)$ & $336.84(23.75)$ & 1418.53 & 12.14 & 3.78 & 15.91 \\
\hline 1994-95 & $1221.12(75.97)$ & $386.27(24.03)$ & 1607.39 & 11.68 & 3.69 & 15.37 \\
\hline 1995-96 & $1398.61(78.45)$ & $384.14(21.55)$ & 1782.75 & 11.40 & 3.13 & 14.53 \\
\hline 1996-97 & $1589.33(79.07)$ & $420.74(20.93)$ & 2010.07 & 11.20 & 2.96 & 14.16 \\
\hline 1997-98 & $1803.35(77.71)$ & $517.18(22.29)$ & 2320.53 & 11.47 & 3.29 & 14.76 \\
\hline 1998-99 & 2164.61(77.49) & $628.78(22.51)$ & 2793.40 & 12.00 & 3.49 & 15.49 \\
\hline 1999-00 & $2490.78(83.57)$ & $489.75(16.43)$ & 2980.53 & 12.38 & 2.43 & 14.81 \\
\hline 2000-01 & $2778.39(85.33)$ & $477.53(14.67)$ & 3255.92 & 12.81 & 2.20 & 15.01 \\
\hline 2001-02 & $3014.68(83.21)$ & $608.42(16.79)$ & 3623.10 & 12.84 & 2.59 & 15.43 \\
\hline 2002-03 & $3387.13(81.96)$ & $745.35(18.04)$ & 4132.48 & 13.38 & 2.95 & 16.33 \\
\hline 2003-04 & $3620.74(76.84)$ & $1091.29(23.16)$ & 4712.03 & 12.76 & 3.85 & 16.60 \\
\hline 2004-05 & $3843.29(77.14)$ & $1139.23(22.86)$ & 4982.52 & 11.85 & 3.51 & 15.37 \\
\hline 2005-06 & $4393.76(86.88)$ & $663.62(13.12)$ & 5057.38 & 11.90 & 1.80 & 13.69 \\
\hline 2006-07 & $5146.09(88.21)$ & $687.78(11.79)$ & 5833.87 & 11.98 & 1.60 & 13.58 \\
\hline 2007-08 & $5944.33(83.41)$ & $1182.38(16.59)$ & 7126.71 & 11.92 & 2.37 & 14.29 \\
\hline 2008-09 & $7937.98(89.80)$ & $901.58(10.20)$ & 8839.56 & 14.10 & 1.60 & 15.70 \\
\hline 2009-10 & $9118.09(89.00)$ & $1126.78(11.00)$ & 10244.87 & 14.12 & 1.74 & 15.87 \\
\hline 2010-11 & $10407.23(86.92)$ & $1566.05(13.08)$ & 11973.28 & 13.56 & 2.04 & 15.60 \\
\hline
\end{tabular}




\begin{tabular}{l}
\hline $\mathbf{2 0 1 1 - 1 2} \mid$\begin{tabular}{l|l|l|l|l|}
\cline { 2 - 2 } \\
\hline
\end{tabular} \\
*Figures for 2011-12 are revised estimates. \\
Source: Government of India, ministry of finance, Indian public finance statistics, $2011-12$.
\end{tabular}

\section{VIII.I. Pre Reform Period}

In the 1980s the major thrust of the government was improved infrastructure and rural development, therefore, the investments to GDP ratio were high. Capital Expenditures were very high during this period. Table 6 shows that the interest payments grew from 1.74 percent of the GDP in 1980-81 to 3.67 percent in 1990-91, accounting for a large portion of governments Revenue Expenditures and creating a debt trap in the 1980s. Subsidies increased from 1.36 percent in 1980-81 to 2.07 percent in 1990-91. Defence Expenditures during this period were high staying above 2 percent of GDP throughout. In 1986-87 the Revenue Expenditures as a percentage of GDP increased by almost 1 percent, from 11.72 percent in 1985-86 to 12.61 percent in 198687 due to implementation of the fourth pay commission. Revenue Expenditures as a percentage of GDP shows an increase of almost 3 percent in this decade, from 9.63 percent in 1980-81 to 12.79 percent in 1989-90. The Capital Expenditures on the other hand increases from 5.59 percent in 1980-81 to 5.72 percent in 1989-90(Table 5). Thus, the increase in Revenue Expenditures was much more than Capital Expenditures. However, increase in Capital Expenditures was the maximum in this decade as compared to the periods afterwards. The components of capital expenditures are seen in Table 6 and it reveals that the Loans and Advances as a percent of GDP was 3.53 percent in 1980-81, remaining more than 3 percent throughout this decade and the capital outlays was more than 2 percent throughout. The compound increase in Capital Expenditure for this decade was 13.13 percent as compared to 4.42 percent in 1990s. The compound rate of growth of Revenue Expenditures was 16.12 percent (Table 5)

Thus, in 1980-81, Revenue Expenditures averaged 63.29 percent of Total Expenditures and increased to 69.11 percent in 1989-90 with the bulk of the expansion coming under the heads of defence, interest payments, higher salaries (Fourth Pay Commission) and subsidies. The Capital Expenditures share in Total Expenditures declined from 36.71 percent to 30.89 percent during the same period (Table 4). Within Revenue Expenditures, in 1980-81, defence expenditures had the highest share of 22.75 percent; interest component was 18.07 percent while subsidies were 14.07 percent. However, by 1990-91, the largest component was the interest share of 29.24 percent with subsidies constituting 16.54 percent and defence only 14.79 percent (Table 7). Therefore, we observe that besides the burden of servicing the public debt, the subsidy burden was also quite great.

\section{VIII.II. Post Reform Period}

Finances of the government had reached a critical stage in 1990-91. The government expenditures stood at 17.96 percent of GDP in the 1990-91, falling after the reforms of 1991, reaching 14.81 percent in 19992000. Compression in Total Expenditures was sought mainly on account of reduction in Capital Expenditures as a percentage of GDP. As a percentage of GDP, Capital Expenditures fell from 5.42 percent in 1990-91 to 2.20 percent in 2000-01, indicating that such expenditures had borne the major burden of fiscal adjustment (Table 4). Table 6 reveals that loans and advances as a percent of GDP reduced to 1.06 percent in 2000-01 and capital outlays came down to 1.14 percent in 2000-01. Revenue Expenditures continued to stay high in the range of around 12 percent in the 1990s mainly because of increase in the interest expenditures from 3.67 percent in 1990-91 to 4.49 percent in 1999-2000. However, a sharp increase in salaries and pensions following the acceptance of the Fifth Pay Commission report in 1996-97 pushed the Revenue Expenditures as a percentage of GDP from 11.20 percent to 12.00 percent in 1998-99 and 12.84 percent in 2001-02. It continued to rise till 2003-04, until the FRBM Act was announced where it stood at 13.38 percent. Capital Expenditures rose till 2003-04 on account of increased investments in different sectors and were recorded at 3.85 percent during that year. After the FRBM was passed, the Central Government's Total Expenditures fell from 16.60 percent in 2003-04 to 14.29 percent in 2007-08. In 2008-09, the Revenue Expenditures jumped up to 14.10 percent from 11.92 percent in 2007-08. During this year the capital expenditures once again suffered a blow. The capital outlays as a percent of GDP came down to 1.35 percent in 2008-09 from 2.14 percent in 2007-08. In 2008-09 the government had an expansionary fiscal stance in the form of a rural farm loan waiver scheme, the expansion of social security schemes under the National Rural Employment Guarantee Act (NREGA) and the implementation of revised salaries and compensations for the central public servants as per the recommendations of the Sixth Pay Commission when the global financial crisis erupted. Furthermore, the parliamentary elections of 2008 also resulted in higher government expenditures (Kumar and Soumya, 2010). To meet the crisis, the government activated a series of stimulus packages in December 2008, January 2009 and February 2009. Subsequently, with the partial withdrawal of the stimulus packages and cutting down of petroleum subsidies the Total Expenditures has started a downtrend and have fallen to 14.89 percent in 2011-12. Revenue Expenditures fell down to 13.12 percent in 2011-12 marking the recovery of the economy. 
The composition of Total Expenditures was skewed in favour of Revenue Expenditures during the nineties and the ratio of Revenue Expenditures in Total Expenditures increased from 69.82 percent in 1990-91 to 85.33 percent in 2000-01. Capital Expenditures as a percentage of Total Expenditures reduced from 30.18 percent to 14.67 percent during this period. In 2000-01, of the Central Governments Revenue Expenditures, 9.66 percent went to subsidies, 13.40 percent to defence and 35.75 percent to interest. As a component of aggregate disbursements of the Central Government, the interest component continued to rise till around 2002-03 and then started to decline. Capital disbursements showed just the opposite trend, falling till around 2002-03 and then rising till 2007-08. The year 2003-04 witnessed an improvement in composition of expenditures with Revenue Expenditures declining to 77.14 percent in 2004-05 and Capital Expenditures increasing to 22.86 percent (Table 4). This was facilitated by a decline in major subsidies, lower growth in Interest Expenditures and pension reforms.

Table 5: Compound Rates of Growth of Components of Revenue and Capital Expenditures

\begin{tabular}{|l|l|l|l|l|l|l|l|l|}
\hline Decade & $\begin{array}{c}\text { Revenue } \\
\text { Expenditur } \\
\text { e }\end{array}$ & Defence & Interest & Subsidies & $\begin{array}{c}\text { Capital } \\
\text { Expendit } \\
\text { ure }\end{array}$ & $\begin{array}{c}\text { Capital } \\
\text { outlay }\end{array}$ & $\begin{array}{c}\text { Loans and } \\
\text { advances } \\
\text { Expendi } \\
\text { ture }\end{array}$ \\
\hline $\mathbf{1 9 8 0 - 8 9}$ & 16.12 & 12.01 & 21.16 & 17.84 & 13.13 & 14.41 & 12.32 & 15.10 \\
\hline $\mathbf{1 9 9 0 - 9 9}$ & 12.98 & 12.47 & 15.43 & 7.25 & 4.42 & 7.08 & 2.41 & 10.97 \\
\hline $\mathbf{2 0 0 0 - 1 0}$ & 12.62 & 9.31 & 7.93 & 18.07 & 8.96 & 14.64 & -3.78 & 12.15 \\
\hline
\end{tabular}

*self calculations on the basis of data compiled from Indian public finance statistics, 2011-12.

The compound rate of growth of Capital Expenditures was much higher in the decade 2000-10 at 8.96 percent as compared to 4.42 percent in the previous decade. On the other hand, the compound rate of growth of revenue account stayed almost in the same range, falling slightly from 12.98 percent in the nineties to 12.62 percent in the 2000s(Table 5).

Table 6: Components of Revenue and Capital Expenditures as a percentage of GDP

\begin{tabular}{|c|c|c|c|c|c|}
\hline Year & $\begin{array}{c}\text { Defence } \\
\text { Expenditures }\end{array}$ & $\begin{array}{c}\text { Interest } \\
\text { payments }\end{array}$ & Subsidies & $\begin{array}{l}\text { Loans and } \\
\text { advances }\end{array}$ & Capital outlay \\
\hline $1980-81$ & 2.19 & 1.74 & 1.36 & 3.53 & 2.05 \\
\hline 1981-82 & 2.19 & 1.82 & 1.10 & 3.22 & 2.39 \\
\hline 1982-83 & 2.29 & 2.00 & 1.15 & 3.76 & 2.37 \\
\hline 1983-84 & 2.27 & 2.09 & 1.27 & 3.52 & 2.28 \\
\hline 1984-85 & 2.46 & 2.33 & 1.57 & 3.58 & 2.63 \\
\hline 1985-86 & 2.43 & 2.59 & 1.66 & 3.83 & 2.64 \\
\hline 1986-87 & 2.83 & 2.85 & 1.68 & 3.95 & 2.86 \\
\hline 1987-88 & 2.41 & 3.06 & 1.62 & 3.47 & 2.52 \\
\hline 1988-89 & 2.19 & 3.27 & 1.77 & 3.38 & 2.35 \\
\hline 1989-90 & 2.03 & 3.54 & 2.09 & 3.37 & 2.35 \\
\hline $1990-91$ & 1.85 & 3.67 & 2.07 & 3.35 & 2.07 \\
\hline 1991-92 & 1.70 & 3.95 & 1.82 & 2.63 & 1.64 \\
\hline $1992-93$ & 1.56 & 4.01 & 1.40 & 2.10 & 1.73 \\
\hline 1993-94 & 1.68 & 4.12 & 1.30 & 2.29 & 1.47 \\
\hline 1994-95 & 1.57 & 4.21 & 1.13 & 2.27 & 1.42 \\
\hline 1995-96 & 1.54 & 4.08 & 1.03 & 1.98 & 1.15 \\
\hline 1996-97 & 1.48 & 4.19 & 1.09 & 1.96 & 1.00 \\
\hline 1997-98 & 1.66 & 4.17 & 1.18 & 2.17 & 1.11 \\
\hline 1998-99 & 1.66 & 4.32 & 1.31 & 2.44 & 1.04 \\
\hline 1999-00 & 1.75 & 4.49 & 1.22 & 1.24 & 1.19 \\
\hline 2000-01 & 1.72 & 4.58 & 1.24 & 1.06 & 1.14 \\
\hline 2001-02 & 1.62 & 4.58 & 1.33 & 1.46 & 1.13 \\
\hline 2002-03 & 1.61 & 4.66 & 1.72 & 1.25 & 1.15 \\
\hline 2003-04 & 1.52 & 4.37 & 1.56 & 1.01 & 1.0 \\
\hline 2004-05 & 1.35 & 3.92 & 1.42 & 0.89 & 1.61 \\
\hline 2005-06 & 1.31 & 3.59 & 1.29 & 0.31 & 1.49 \\
\hline
\end{tabular}


Growth of the Public Expenditures in India and its impact on the Deficits

\begin{tabular}{|l|l|l|l|l|l|}
$\mathbf{2 0 0 6 - 0 7}$ & 1.20 & 3.50 & 1.33 & 0.20 & 1.40 \\
\hline $\mathbf{2 0 0 7 - 0 8}$ & 1.09 & 3.43 & 1.42 & 0.23 & 2.14 \\
\hline $\mathbf{2 0 0 8 - 0 9}$ & 1.30 & 3.41 & 2.30 & 0.25 & 1.35 \\
\hline $\mathbf{2 0 0 9 - 1 0}$ & 1.40 & 3.30 & 2.19 & 0.24 & 1.50 \\
\hline $\mathbf{2 0 1 0 - 1 1}$ & 1.20 & 3.05 & 2.26 & 0.52 & 1.52 \\
\hline $\mathbf{2 0 1 1 - 1 2}$ & 1.18 & 3.11 & 2.44 & 0.24 & 1.53 \\
\hline
\end{tabular}

*Figures for 2011-12 are revised estimates.

Source: Government of India, ministry of finance, Indian public finance statistics, 2011-12.

Table 7: Components of Revenue Expenditures

\begin{tabular}{|c|c|c|c|c|c|c|}
\hline \multirow[b]{2}{*}{ Year } & \multicolumn{3}{|c|}{ Rs. billion } & \multicolumn{3}{|c|}{ As a percent of Revenue Expenditures } \\
\hline & $\begin{array}{c}\text { Defence } \\
\text { Expenditures }\end{array}$ & $\begin{array}{c}\text { Interest } \\
\text { payments }\end{array}$ & Subsidies & $\begin{array}{c}\text { Defence } \\
\text { Expenditures }\end{array}$ & $\begin{array}{c}\text { Interest } \\
\text { payments }\end{array}$ & Subsidies \\
\hline 1980-81 & 32.78 & 26.04 & 20.28 & 22.75 & 18.07 & 14.07 \\
\hline 1981-82 & 38.44 & 31.95 & 19.41 & 24.95 & 20.74 & 12.60 \\
\hline $1982-83$ & 44.94 & 39.38 & 22.62 & 23.98 & 21.01 & 12.07 \\
\hline 1983-84 & 51.89 & 47.95 & 29.02 & 23.32 & 21.55 & 13.04 \\
\hline 1984-85 & 63.24 & 59.74 & 40.38 & 22.84 & 21.57 & 14.58 \\
\hline 1985-86 & 70.21 & 75.12 & 47.96 & 20.70 & 22.14 & 14.14 \\
\hline 1986-87 & 91.79 & 92.46 & 54.51 & 22.46 & 22.63 & 13.34 \\
\hline 1987-88 & 88.61 & 112.51 & 59.80 & 19.19 & 24.37 & 12.95 \\
\hline 1988-89 & 95.58 & 142.78 & 77.32 & 17.67 & 26.39 & 14.29 \\
\hline 1989-90 & 101.94 & 177.57 & 104.74 & 15.88 & 27.65 & 16.31 \\
\hline 1990-91 & 108.74 & 214.98 & 121.58 & 14.79 & 29.24 & 16.54 \\
\hline 1991-92 & 114.42 & 265.96 & 122.53 & 13.90 & 32.32 & 14.89 \\
\hline 1992-93 & 121.09 & 310.75 & 108.24 & 13.06 & 33.52 & 11.68 \\
\hline 1993-94 & 149.78 & 367.41 & 116.05 & 13.85 & 33.97 & 10.73 \\
\hline 1994-95 & 164.26 & 440.60 & 118.54 & 13.45 & 36.08 & 9.71 \\
\hline 1995-96 & 188.41 & 500.45 & 126.66 & 13.47 & 35.78 & 9.06 \\
\hline 1996-97 & 209.97 & 594.78 & 154.99 & 13.21 & 37.42 & 9.75 \\
\hline 1997-98 & 261.74 & 656.37 & 185.40 & 14.51 & 36.40 & 10.28 \\
\hline 1998-99 & 298.61 & 778.82 & 235.93 & 13.80 & 35.98 & 10.90 \\
\hline 1999-00 & 352.16 & 902.49 & 244.87 & 14.14 & 36.23 & 9.83 \\
\hline 2000-01 & 372.38 & 993.14 & 268.38 & 13.40 & 35.75 & 9.66 \\
\hline 2001-02 & 380.59 & 1074.60 & 312.10 & 12.62 & 35.65 & 10.35 \\
\hline $2002-03$ & 407.09 & 1178.04 & 435.33 & 12.02 & 34.78 & 12.85 \\
\hline 2003-04 & 432.03 & 1240.88 & 443.23 & 11.93 & 34.27 & 12.24 \\
\hline 2004-05 & 438.62 & 1269.34 & 459.57 & 11.41 & 33.03 & 11.96 \\
\hline 2005-06 & 482.11 & 1326.30 & 475.22 & 10.97 & 30.19 & 10.82 \\
\hline 2006-07 & 516.82 & 1502.72 & 571.25 & 10.04 & 29.20 & 11.10 \\
\hline 2007-08 & 542.19 & 1710.30 & 709.26 & 9.12 & 28.77 & 11.93 \\
\hline 2008-09 & 733.05 & 1922.04 & 1297.08 & 9.23 & 24.21 & 16.34 \\
\hline 2009-10 & 906.69 & 2130.93 & 1413.51 & 9.94 & 23.37 & 15.50 \\
\hline 2010-11 & 920.61 & 2340.22 & 1734.20 & 8.85 & 22.49 & 16.66 \\
\hline 2011-12 & 1047.93 & 2756.18 & 2162.97 & 9.02 & 23.72 & 18.62 \\
\hline
\end{tabular}

*Figures for 2011-12 are revised estimates.

Source: Government of India, ministry of finance, Indian public finance statistics, 2011-12

\section{EXPENDITURE REFORMS AND DEFICITS}

The sharp increase in Expenditures in the eighties as compared to the modest increase in tax and non tax revenues resulted in high revenue and fiscal deficits by the end of the decade. Table 8 shows that in the 
eighties the Total Expenditures and Revenue Expenditure were increasing and hence the Revenue Deficit climbed from 1.36 percent of GDP in 1980-81 to 3.17 percent of GDP in 1990-91 and the Gross Fiscal Deficit climbed from 5.55 percent to 7.61 percent of GDP. To maintain the momentum of development, during this period the government set a high target for expenditures and stuck to it despite increasing deficits.

The immediate response to the economic crisis in 1991 was to compress expenditures, and the focus was on reducing subsidies. Simultaneously, the softer options of reducing public investment expenditures and reducing public expenditures on social welfare services were also resorted to. In the nineties, the government decided to subject all plan and non-plan schemes to Zero Based Budgeting (ZBB). ZBB implies constructing a budget without reference to past expenditures, based on a fundamental reappraisal of purposes, methods and resources. While the programme of privatization or disinvestment in central PSUs remained low key through the 1990s, it started to gather momentum from 2001-02. To give a greater thrust to the process of disinvestments, a separate department was set up. 2002-03 onwards, fresh recruitments were restricted to one percent of the total civilian staff strength of the government. A decision to reform the pension system for government employees by introducing a pay as you go, as opposed to existing fully funded system was also taken. An Expenditures Reforms Commission was constituted in February, 2000 to delve into the process of reducing the growth in nondevelopmental expenditures. It submitted several reports covering aspects like buffer stock operation and rationalization of fertilizer subsidies, optimizing government staff strength with a ban on the creation of new posts for two years, introduction of VRS and redeployment of surplus staff in various government departments and autonomous institutions funded by government budgetary support.

Table 8: Expenditures and Deficits of the Central Government

\begin{tabular}{|c|c|c|c|c|c|c|}
\hline \multirow[b]{2}{*}{ Year } & \multirow{2}{*}{$\begin{array}{c}\text { Gross Fiscal } \\
\text { Deficit } \\
\text { (Rs. Billion) }\end{array}$} & \multirow[b]{2}{*}{$\begin{array}{l}\text { Revenue Deficit } \\
\text { (Rs. Billion) }\end{array}$} & \multicolumn{4}{|c|}{ As a percent of GDP } \\
\hline & & & $\begin{array}{c}\text { Revenue } \\
\text { Expenditures }\end{array}$ & $\begin{array}{c}\text { Total } \\
\text { Expenditures }\end{array}$ & $\begin{array}{l}\text { Gross Fiscal } \\
\text { Deficit }\end{array}$ & $\begin{array}{c}\text { Revenue } \\
\text { Deficit }\end{array}$ \\
\hline 1980-81 & 82.99 & 20.37 & 9.63 & 15.21 & 5.55 & 1.36 \\
\hline 1981-82 & 86.66 & 3.84 & 8.76 & 14.37 & 4.93 & 0.22 \\
\hline $1982-83$ & 106.27 & 13.08 & 9.53 & 15.66 & 5.40 & 0.67 \\
\hline 1983-84 & 130.30 & 25.40 & 9.72 & 15.52 & 5.69 & 1.11 \\
\hline 1984-85 & 174.16 & 42.25 & 10.79 & 17.00 & 6.79 & 1.65 \\
\hline 1985-86 & 218.58 & 58.89 & 11.72 & 18.19 & 7.55 & 2.03 \\
\hline 1986-87 & 263.42 & 77.77 & 12.61 & 19.42 & 8.13 & 2.40 \\
\hline 1987-88 & 270.44 & 91.37 & 12.54 & 18.54 & 7.34 & 2.48 \\
\hline 1988-89 & 309.23 & 105.15 & 12.38 & 18.11 & 7.08 & 2.41 \\
\hline 1989-90 & 356.32 & 119.14 & 12.79 & 18.51 & 7.10 & 2.37 \\
\hline 1990-91 & 446.32 & 185.62 & 12.54 & 17.96 & 7.61 & 3.17 \\
\hline 1991-92 & 363.25 & 162.62 & 12.21 & 16.53 & 5.39 & 2.41 \\
\hline 1992-93 & 401.73 & 185.74 & 11.97 & 15.83 & 5.19 & 2.40 \\
\hline 1993-94 & 602.57 & 327.16 & 12.14 & 15.91 & 6.76 & 3.67 \\
\hline 1994-95 & 577.03 & 310.29 & 11.68 & 15.37 & 5.52 & 2.97 \\
\hline 1995-96 & 602.43 & 297.31 & 11.40 & 14.53 & 4.91 & 2.42 \\
\hline 1996-97 & 667.33 & 326.54 & 11.20 & 14.16 & 4.70 & 2.30 \\
\hline 1997-98 & 889.37 & 464.49 & 11.47 & 14.76 & 5.66 & 2.95 \\
\hline 1998-99 & 1133.49 & 669.76 & 12.00 & 15.49 & 6.29 & 3.71 \\
\hline 1999-00 & 1047.16 & 675.96 & 12.38 & 14.81 & 5.20 & 3.36 \\
\hline $2000-01$ & 1188.16 & 852.34 & 12.81 & 15.01 & 5.48 & 3.93 \\
\hline 2001-02 & 1409.55 & 1001.62 & 12.84 & 15.43 & 6.00 & 4.27 \\
\hline 2002-03 & 1450.72 & 1078.79 & 13.38 & 16.33 & 5.73 & 4.26 \\
\hline 2003-04 & 1232.73 & 982.61 & 12.76 & 16.60 & 4.34 & 3.46 \\
\hline 2004-05 & 1257.94 & 783.38 & 11.85 & 15.37 & 3.88 & 2.42 \\
\hline 2005-06 & 1464.35 & 922.99 & 11.90 & 13.69 & 3.96 & 2.50 \\
\hline 2006-07 & 1425.73 & 802.22 & 11.98 & 13.58 & 3.32 & 1.87 \\
\hline 2007-08 & 1269.12 & 525.69 & 11.92 & 14.29 & 2.54 & 1.05 \\
\hline 2008-09 & 3369.92 & 2535.39 & 14.10 & 15.70 & 5.99 & 4.50 \\
\hline 2009-10 & 4184.82 & 3389.98 & 14.12 & 15.87 & 6.48 & 5.25 \\
\hline
\end{tabular}




\begin{tabular}{|l|l|l|l|l|l|l|}
\hline 2010-11 & 3735.91 & 2522.52 & 13.56 & 15.60 & 4.87 & 3.29 \\
\hline 2011-12 & 5219.80 & 3949.51 & 13.12 & 14.89 & 5.89 & 4.46 \\
\hline
\end{tabular}

*Figures for 2011-12 are revised estimates.

Source: Government of India, ministry of finance, Indian public finance statistics, 2011-12.

These measures did help reduce the Total Expenditures and Fiscal Deficit of the Central Government in the nineties and the gross fiscal deficit as a percentage of GDP came down to 5.48 percent in 2000-01 from 7.61 percent in 1990-91.The Central Government's Revenue Deficit however did not show a declining trend and stood at 3.93 percent of GDP. This was because the Revenue Expenditure had increased during this period from 12.54 percent in 1990-91 to 12.81 percent in 2000-01.

Fiscal discipline again seemed to waver in the early 2000s. The central governments revenue deficit climbed to 4.4 percent of GDP in 2002-03 while the Gross Fiscal Deficit was at 5.91 percent of the GDP. To control this, a new fiscal discipline framework, FRBMA was adopted in 2003. This act gave a medium term target for balancing current revenues and expenditures and set overall limits to the Fiscal Deficit at 3 percent of GDP, to be achieved according to a phased deficit reduction roadmap. These fiscal discipline legislations seemed to have had a good impact. In 2007-08, the year before the global financial crisis, the Central Government's Revenue Expenditure was 11.92 percent and the Total Expenditure was 14.29 percent of GDP. Accordingly, the Revenue Deficit came down to 1.05 percent of GDP while the Gross Fiscal Deficit was 2.54 percent. In 2008-09 the economy was hit by multiple shocks. The growth of Revenue Expenditures in 2008-09 was notable due to the fiscal stimulus packages provided by the government to revive the economy and went up to 14.10 percent. This resulted in the overall Fiscal Deficit expending from less than 3 percent in 2007-2008 to 5.99 percent in 2008-09.

Following two years of purposeful fiscal expansion, the Budget for 2010-11 resumed fiscal consolidation with a partial rollback of the stimulus. The expenditures declined and so did the Fiscal deficit which declined to 4.87 per cent of GDP in 2010-11 from 6.48 per cent in 2009-10. But, once again the fiscal balance deteriorated in 2011-12 even though the expenditures were declining. This was caused by high global crude oil prices and lower tax receipts which pushed the Fiscal Deficit to 5.89 per cent of GDP in 2011-12. Simultaneously, the Revenue Deficit increased to 4.46 percent as compared to 3.29 percent in the previous year.

\section{SUGGESTIONS}

The Government needs to focus on the reducing the Revenue Expenditures and increasing the growth rate of Capital Expenditures. Greater detail is required on better targeting of social expenditures to achieve fiscal consolidation while maintaining the process of growth. Expenditures need to be reorientated to contain the deficits, whilst providing adequate outlays for essential social sectors like education, health etc. The Government needs to strengthen the public distribution system for better targeting of subsidies, bring in efficiencies and make the system more transparent. Energy subsidies are high and need to be curtailed. Overstaffing in Government departments has led to low productivity and inefficiencies, hence downsizing of staff is essential. There is also a need to focus on transparency in fiscal operations. Moreover, wide ranging reforms are required to remove the structural bottlenecks and increase the growth rate. To ensure 100 percent utility of funds a special committee is required to monitor expenditures. Finally a reform in the accounting and budgeting process, improved management and control of government expenditures is vital.

\section{CONCLUSION}

An analysis of the Central Government expenditures shows that the increase in the Non-Plan Expenditures has been almost 65 times from Rs. 137.74 billion in 1980-81 to Rs. 8921.16 billion in 2011-12. At the same time the Plan Expenditures have increased by 47 times from Rs. 89.94 billion to Rs. 4266.04 billion in 2011-12. The Total Expenditures of the Central Government have been rapidly increasing since the 1980s and was Rs. 227.68 billion in 1980-81, increasing by almost 60 times to Rs. 13187.20 billion in 2011-12. This increase is mainly attributed to an increase in Revenue Expenditures at the cost of Capital Expenditures. As the Fiscal and Revenue Deficits increased throughout the period of the study, the Capital Expenditures were suppressed post reforms to bring down the deficits, since the government was unable to contain the Revenue Expenditures. This state of affairs raised an extreme concern about the future growth prospects of the Indian economy. 


\section{References}

[1] India: Fiscal reforms and public Expenditures management, JBIC Research Paper No. 11, Japan Bank for International Cooperation (JBIC), March 2001.

[2] Kumar, Rajiv and Alamuru Soumya. 2010, Fiscal Policy Issues for India after the Global Financial Crisis (2008-2010). Asian Development Bank Institute, Working Paper No. 249

[3] M. Govinda Rao, The fiscal situation and a reform agenda for the new government, Economic and Political Weekly, volume 44, no.25, June 20, 2009.

[4] M. Govinda Rao, Sen T.K. and Ghosh, M., Uneven Growth of Government Expenditure in India: An Analysis of the Trends between 1974-75 and 1990-91, Journal of Indian School of Political Economy, No.7, 1995

[5] Nirvikar Singh T. N. Srinivasan, Fiscal Policy in India: Lessons and Priorities, February 17, 2004, NIPFP-IMF conference paper on Fiscal Policy in India January, 2004.

[6] Web resources:

-www.rbi.org.in.

- Indian public finance statistics, GOI, ministry of finance, 2011-12. 